Finally, in 1894, at the International Geological Congress of Zurich he intiated the formation of the "Commission Internationale des Glaciers," being himself elected representative for Great Britain and the Colonies.

A wide field had in this way been found for the exercise of his energies, and there seemed every prospect that he might continue to do much good work, when, to the great sorrow of his family and numerous friends, he was carried off, after a short illness, at the age of 65 , just as his plans for the universal study of glacier action were beginning to bear fruit.

Marshall Hall is not to be estimated merely by his writings, which, like his speeches, were for the most part exceedingly brief. His strength rather lay in his faculty of bringing men together, and for this purpose his genial disposition and agreeable manners eminently qualified him. In the beyday of life he discharged these functions in a generous and hospitable spirit. Unfortunately, as time went on, his physical infirmity of deafness, in conjunction with other causes, tended to withdraw him from society at large, though never from social intercourse. To the last he struggled bravely against all these difficulties, frequently busy, but, as he says in a letter written a few months before his death, grown older and less inclined to work. "Not that I am often idle," he remarks; "things come in all of a heap, then comparative repose, then more work. 'There will not be much to show for sundry years, even if I got folks to do anything systematic. So far, the New Zealanders are my best men."

Those sundry years he was not destined to realize, and now that the originator is gone will the work be continued?

\title{
HENRY JAMES SLACK, F.G.S., F.R.M.S.
}

BonN Octoper 23, 1818. Died JUNB 16, 1896.

Among the pioneers of science, more especially interested in the promotion of microscopical investigations in Biology, the name of Henry James Slack must be engraved upon the annals of the present century, of which his life had covered nearly 78 years.

H. J. Slack was educated at Dr. Evans' school, North End, Hampstead, and at the age of seventeen he entered a wool-broker's office in the City, in which be speedily became a partner, but he retired in 1846, finding the business uncongenial to his literary and scientific inclinations: he then devoted himself to legal and forensic studies, and was in due course "called," but although a keen debater, and intensely fond of either a scientific or political discussion, he never practised at the Bar.

Whilst residing at Ilfracombe, in 1849 , he wrote several articles which appeared in the North Devon Journal, and in 1852 he became proprietor and editor of the Atlas newspaper, to which Walter Savage Landor contributed some poems on Garibaldi. $\mathrm{He}_{\boldsymbol{\theta}}$ also acted as temporary editor of the Westminster Quarterly; and contributed numerous articles both to newspapers and other 
periodical publications. In 1860 Henry James Slack commenced to write leaders for the Weekly Times, which he continued until 1884.

Keenly alive to all political and social reforms, and spending his time and money most generously in the cause of national and unsectarian education, he was at the same time earnestly devoted to scientific pursuits. He joined the Geological Society of London in 1849 (having been at the time of his death a Fellow for 47 years). Among his numerons scientitic papers three only bear directly on Geology, namely: "On Coccoliths and Coccospheres in Reigate Sandstone"; "Notes on the Comparative Geology of the Earth and Moon"; and "Life Changes on the Globe."

One of his most valuable labours for the promotion of science was the editing of Recreative Science (published by Messrs. Groombridge and Sons), which was enlarged successively into the Intellectual Observer, and lastly into the Student. As the popular exponent of science, this periodical occupied, for about twenty years, a first-class position, and possibly might have survived even to the present day, but for the triple dangers of alterations in form, in size, and in title, which it underwent at the hands of its metamorphotic publishers and editor, had not the former terminated their publishing business, and the latter his duties as editor! Dr. S. P. Woodward, Dr. G. S. Brady, Dr. P. Lutley Sclater, Dr. H. Woodward, 1r. P. Martin Duncan, Dr. Wright, Professor Sir Wyville Thomson, and many other distinguished men of science, contributed to Mr. Slack's monthly magazine, and its pages abounded with good scientific articles.

Of the Royal Microscopical Society ho may be said to have been one of the founders, and he filled in succession the offices of Secretary and of President. In addition to the keen interest which Mr. Slack took in all microscopical reseurch, he was also an enthusiastic student of Astronomy, and erected a telescope abont 1867, at his residence in Camden Square, which had some points of novelty, being a Newtonian, mounted equatorially on a stand designed by $\mathrm{Mr}$. Browning and himself, having a silver-on-glass speculum and a prism instead of a mirror at the eye-tube (see Intellectual Observer, vol. ix, p. 276). Always interested in politics and in all matters relating to education and social progress, and being a strong democrat in principles, in 1879 , when President of the National Sunday League, he instituted Sunday Evening Entertainments for the People, giving popular scientific lectures himself, with illustrations, and always with selections of good classical music.

His scientific papers mostly appeared in the Intellectual Observer and Student, and bear chiefly upon microscopical research. Some of his work on Infusoria was published in a small book entitled "Marvels of Pond Life," which passed through three editions.

In later years Mr. Slack removed from London to a delightful country residence, Ashdown Cottage, Forest Row, Sussex, where ho spent the last ten or fifteen years of his always happy, busy, literary and scientific life. 